\title{
microRNA-22 can regulate expression of the long non-coding RNA MEG3 in acute myeloid leukemia
}

\author{
Hongxia Yao ${ }^{1, *}$, Pei Sun ${ }^{2, *}$, Mengling Duan ${ }^{1, *}$, Lie Lin ${ }^{1}$, Yanping Pan ${ }^{1}$, Congming \\ $\mathbf{W u}^{1}$, Xiangjun Fu ${ }^{1}$, Hua Wang ${ }^{1}$, Li Guo ${ }^{1}$, Tianbo Jin $^{3}$ and Yipeng Ding ${ }^{4}$ \\ ${ }^{1}$ Department of Hematology, Hainan General Hospital, Haikou, Hainan 570311, P.R. China \\ ${ }^{2}$ Department of Hematology, Hunan Yiyang Central Hospital, Yiyang, Hunan 413000, P.R. China \\ ${ }^{3}$ Key Laboratory of Resource Biology and Biotechnology in Western China (Northwest University), Ministry of Education, \\ Xi'an, Shaanxi 710069, P.R. China \\ ${ }^{4}$ Department of Emergency, Hainan General Hospital, Haikou, Hainan 570311, P.R. China \\ *These authors have contributed equally to this work \\ Correspondence to: Hongxia Yao, email: yaohongxiahk@163.com \\ Yipeng Ding, email: ypding@263.net \\ Keywords: acute myeloid leukemia(AML), MEG3, long non-coding RNA, TET2, miR-22-3p/5p \\ Received: March 22, $2017 \quad$ Accepted: April 19, $2017 \quad$ Published: May 22, 2017 \\ Copyright: Yao et al. This is an open-access article distributed under the terms of the Creative Commons Attribution License 3.0 \\ (CC BY 3.0), which permits unrestricted use, distribution, and reproductionin any medium, provided the original author and source \\ are credited.
}

\section{ABSTRACT}

Aim: Acute myeloid leukemia (AML) is the most common blood tumor with poor prognosis. At present, the research found that the pathogenesis of AML is related to many factors, such as recurrent somatic mutations and gene expression and epigenetic changes, however, the molecular mechanism of AML is still unclear. Long non-coding RNA MEG3 is a newly found tumor suppressor and plays a very important role in the regulation of a variety of tumor formation and progression. Studies found that the MEG3 expression was significantly decreased in AML. However, to date, it is not clear the cause of its abnormal expression. Therefore, the molecular mechanism of AML is urgently needed to study the molecular mechanism of AML.

Methods: The different expression level of MEG3, TET2, miR-22-3p, miR-22-5p in AML was detected by real-time quantification PCR. MEG3, TET2, miR-22-3p, miR22-3p expression cell pools in $\mathrm{K562}$ cells was used to interfering and TET2, MEG3 TET2, relations with miR-22-3p, miR-22-5p. The effect of AML cell on proliferation was evaluated by TET2 lower expression.

Results: 1. The lower expression of MEG3 and TET2 in AML cell lines was detected by RT-qPCR. 2. The stable MEG3, TET2 overexpression cell pools in $\mathrm{K} 562$ cells was successful established. 3. After transfection, MTT assay revealed that cell growth was significantly increased in AML cell lines transfected with TET2 compared with controls.

Conclusions: Our findings suggested that MEG3 is significantly down regulated in AML cell lines.

\section{INTRODUCTION}

Acute myeloid leukemia (AML) is the most common blood tumor. In recent years, with the rapid development of genetics, molecular biology and sequencing technology, more in-depth understanding of the pathogenesis has been made. Improvements in chemotherapy regimens and supportive therapies, as well as the widespread use of novel drug delivery and hematopoietic stem cell transplantation have significantly improved patient outcomes and outcomes. However, more than young patients and older patients died AML [1]. Moreover, with the industrial development and other factors, the incidence of AML showed an increasing trend year by year [2]. The study found that mutations in AML lead to the abnormal 
regulation of several signal transduction pathways, the potential target is very fragmented [3], therefore, in-depth study of the molecular mechanism for the urgent need of AML, in order to obtain more biomarkers and specific segments or a new target for the treatment.

Long-chain non-coding RNAs(lncRNAs) are noncoding RNAs with a transcription length of more than 200nt, which can regulate chromatin remodeling, histone modification and DNA methylation, and have a profound impact on the development of tumors and other diseases [4]. There is evidence that the expression levels of some lncRNAs are significantly altered in specific malignancies, and the abnormal expression of such lncRNAs can be a diagnostic marker and potential drug target for a particular tumor [5-7]

lncRNA MEG3, a newly discovered lncRNA with tumor suppressor function, plays an important role in the formation and progression of many tumors. The study found that MEG3 in acute myeloid leukemia (AML) in the expression significantly decreased, but its influence on the biological behavior of AML tumors is still unclear. In various tumor tissues, the expression of MEG3 decreased significantly in brain, bladder, breast, cervical, colon, bone marrow, liver, lung and prostate cancer cells in the expression decreased obviously [8-10]. Since MEG3 can promote the binding of tumor suppressor gene P53 to target, the down-regulation of expression may promote the proliferation of tumor cells $[8,11,12]$. In nearly half of the AML, the content of MEG3 decreased significantly [13]. But until now, whether MEG3 activity can affect the growth of AML cells and whether the mechanism can affect the growth of AML cells is not clear.

TET2 gene mutations have been found in a variety of bone marrow malignancies, including acute myeloid leukemia, chronic myelomonocyticleukemia, myelodysplastic syndrome, polycythemiavera, primary myelofibrosis, idiopathic thrombocytosis, mastocytosis et al. [14, 15]. TET protein is a member of the DNA family can catalyze 5- hydroxylase, methyl cytosine demethylation, has very good characteristics of epigenetic modifications, play an important role in regulating gene expression and maintaining cell surface marks [16, 17]. Methylation of DNA is an important force to promote tumor formation and malignant progression, $5 \mathrm{hmC}$ is in the TET 2 enzyme catalyzed by $5 \mathrm{mC}$ oxidation, $5 \mathrm{hmC}$ is a metabolic product of $5 \mathrm{mC}$, which will lead to a decline in $5 \mathrm{mC}$, and demethylation. Thus, reduced TET2 activity leads to changes in DNA methylation patterns (such as promoter hypermethylation)[18]. TET2 inactivation is also an important reason for promoting the occurrence and development of AML. Its inactivation may lead to the demethylation process of DNA damaged, so that the tumor DNA at least in some areas of hypermethylation, and ultimately promote tumor development [19].

The study found that miR- 22 can regulate the expression of TET2 negative, thus reducing the expression of 5 - hydroxy methyl cytosine and enhance methylation of multiple genes.

So, in our study we will to study TET2 inactivation and MEG3 methylation of correlation. To explored the causes of TET2 deactivation to clarify cause MEG3 molecular mechanism of deactivation.

\section{RESULTS}

\section{ExpressionofTET2, MEG3, miR-22-3p, miR-22-5p}

To explore the role of TET2, MEG3, miR-22-3p, miR-22-5p in AML, we analyzed 20 AML and normal counterparts for expression using qRT-PCR. In Figure 1, we found TET2 and MEG3 was signficantly decreased in tumor samples, however, miR-22-3p, miR-22-5p was signficantly increased in tumor samples.

\section{Expression of TET2 gene and MEG3 gene in K562 cells transfected with TET2-siRNA}

Transfected with TET2-siRNA, compared with K562-NC group, the TET2 expression in siRNA1, siRNA2 group was $37 \%, 16 \%$ respectively with difference of statistical significance. Compared with K562-NC group, the MEG3expression in siRNA1, siRNA2 group was $54 \%, 46 \%$ respectively with difference of statistical significance. Transfected with miR-22-3p/5p mimics, and the results showed that the expression of $\mathrm{miR}-22-3 \mathrm{p} / 5 \mathrm{p}$ mimics was obvious. Transfected with $\mathrm{miR}-22-3 \mathrm{p} / 5 \mathrm{p}$ mimics, compared with NC-mimics group, the TET2 expression in the miR-22-3p-mimics, the miR-22-5pmimics group was $65 \%, 97 \%$ respectively with difference of statistical significance. Compared with NC-mimics group, the MEG3 expression in miR-22-3p-mimics, the miR-22-5p-mimics group was $77 \%, 87 \%$ respectively with difference of statistical significance (Figures 2-4).

\section{Detection of cell reproductive capacity}

The change of proliferation capacity of stable cell strains, TET2, miRNA-22-3p/5p siRNA infection was detected by CCK- 8 method. The results showed that the inhibition ratios of cellular proliferation in TET2-siRNA1 group, TET2-siRNA2 group, miRNA-22-3p mimics group andmiRNA-22-5p mimics group were increased. Above results showed that TET2 and MEG3 lower expression can promote the AML proliferation (Figure 5).

\section{DISSCUSION}

Some studies have shown that lncRNAs can regulate multiple signaling pathways in the process of development, and the disorder of lncRNAs regulation may result in the development of tumors by affecting the epigenetic information. Although lncRNAs has an important effect 
on the occurrence of tumor, its mechanism is still unclear. MEG3 is one of the lncRNAs [20]. It was discovered in 2000 by Miyoshi et al., located on chromosome 14q32.3, the mature MEG3 RNA length is about 1600nt [20]. Zhang et al. [11] used in situ hybridization to detect various tissues of human body, and found that MEG3 was expressed in normal tissues such as brain, pituitary, placenta, adrenal gland, pancreas and ovary. However, MEG3 expression missing was found in a variety of tumor cell lines, including brain, bladder, bone marrow, breast, cervix, colon, liver, lung and prostate $[8,11,12,21,22]$. Overexpression of MEG3 gene can inhibit the proliferation of tumor cell lines and act as a tumor suppressor gene. Expressing MEG3 gene has been reported is caused by multiple mechanisms lack in human tumors and tumor cell lines, including the regulation of transcriptional activity mediated by P53 gene
[23], promoter region $\mathrm{CpG}$ island methylation [24] and demethylation effect [22]. In several cancers, the MEG3 promoter was confirmed to have aberrant methylation in the CpG Island [23]. Hypermethylation in 43 patients with myelodysplastic syndrome and 42 cases of acute myeloid leukemia patients were $34.9 \%$ and $47.6 \%$ of the patients with MEG3 promoter, further found that hypermethylation of MEG3 promoter in patients with poor prognosis [13]. These studies suggested that the inactivation of MEG3 gene may be due to the hypermethylation of its promoter. In nearly half of the AML, the content of MEG3 decreased significantly [8]. However, it is not clear whether the decrease of MEG3 activity can affect the growth of AML cells and the mechanism of AML cell growth.

TET gene plays a key role in many biological processes, including the reorganization of fertilized eggs,

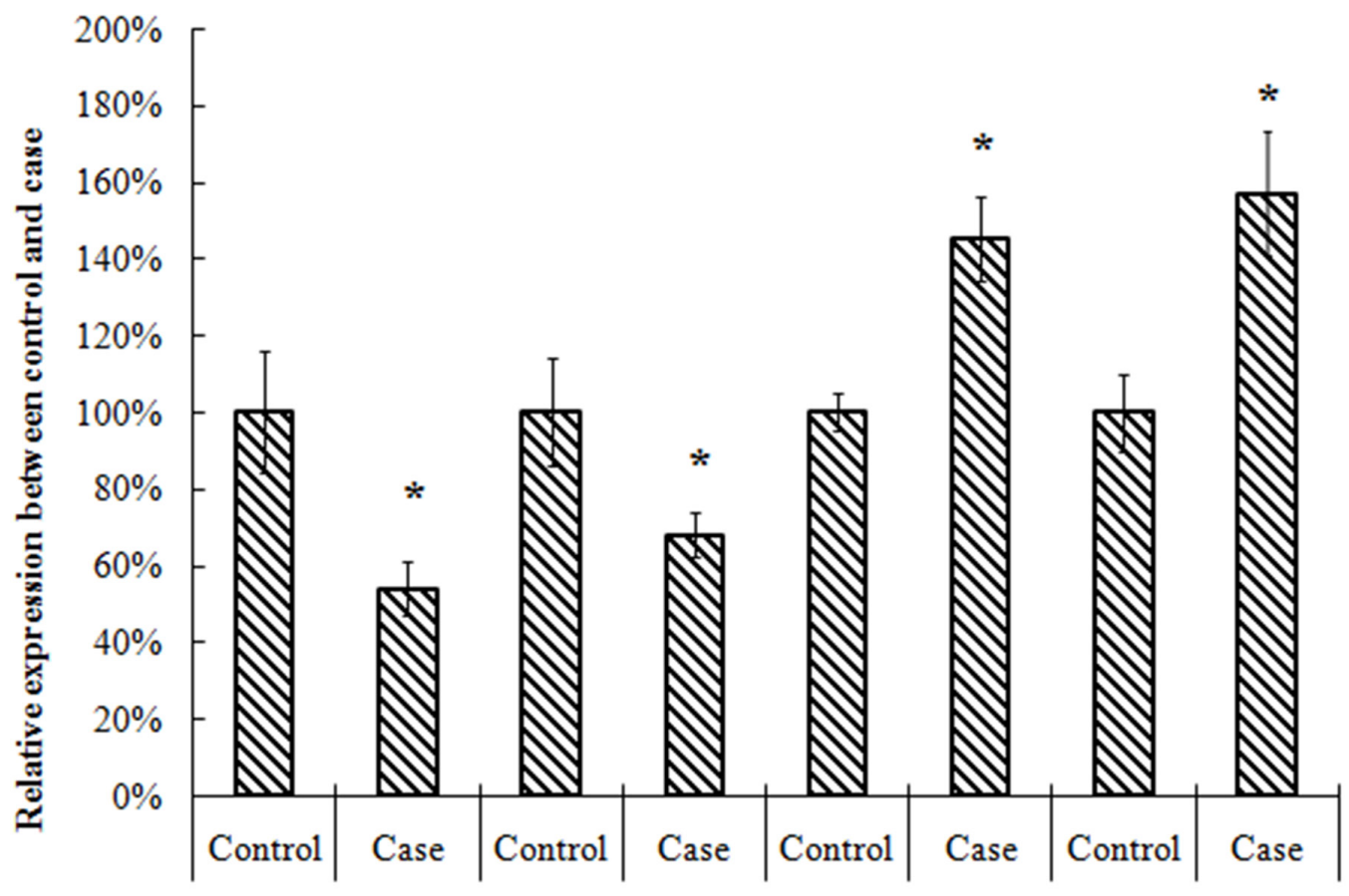

Figure 1: Expression of TET2, MEG3, miR-22-3p, miR-22-5p in AML and control.
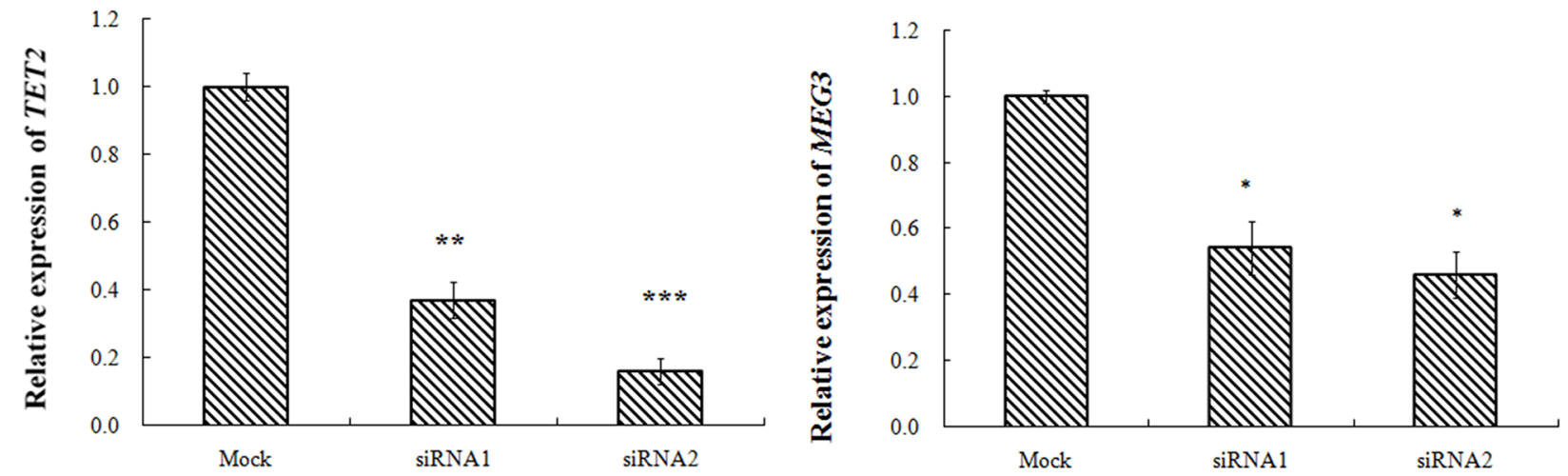

Figure 2: K562 cell transfection TET2-siRNA, MEG3 and TET2 gene expression. 

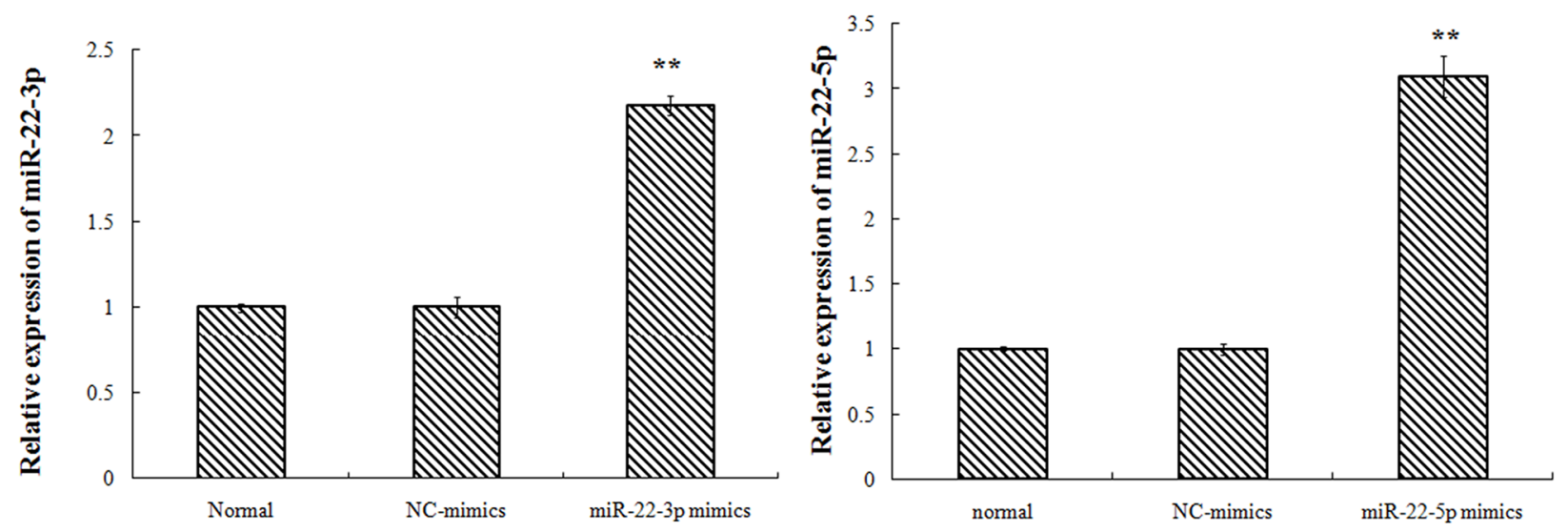

Figure 3: K562 cell transfection miR-22-3p/5p, miR-22-3p/5p expression (the nucleic acid level).
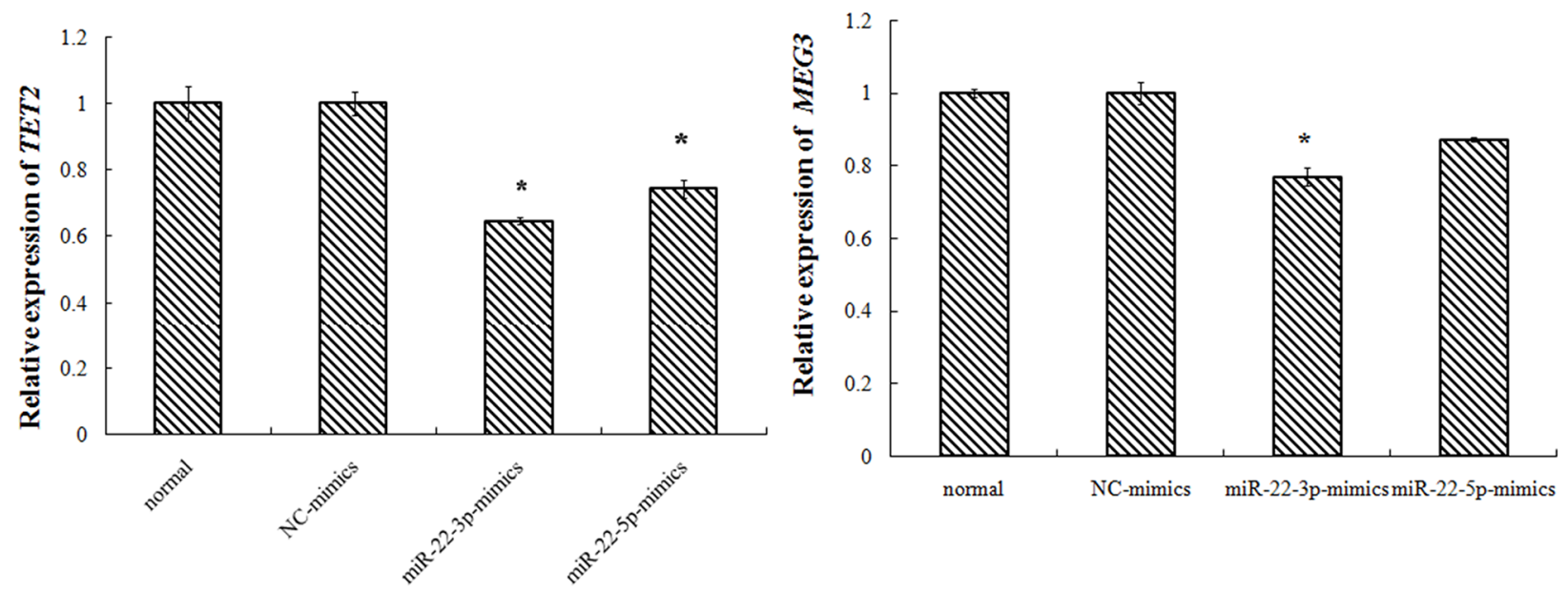

Figure 4: K562 cell transfection miR-22-3p/5p, miR-22-3p/5p expression.

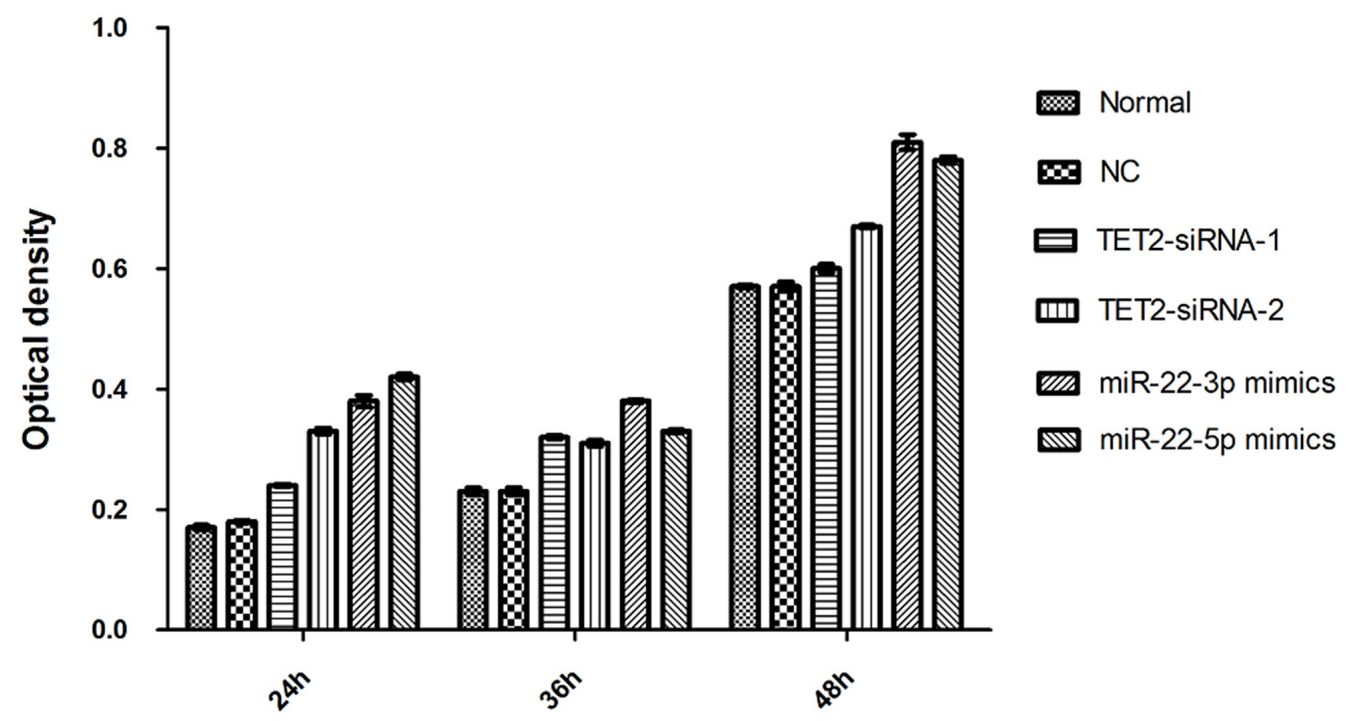

Figure 5: Detection of cell reproductive capacity. 
differentiation of pluripotent stem cells, bone marrow hematopoiesis and the development of leukemia. TET2 gene is located on chromosome 4q24, contains 11 exons, length of $150 \mathrm{~kb}$ [25], is one of the important genes involved in surface epigenetic regulation, to methylation, plays an important role in epigenetic regulation and bone marrow in DNA. The study found in acute myeloid leukemia, myelodysplastic syndrome, chronic true bone marrow mononuclear cell leukemia, polycythemia, thrombocytosis, primary myelofibrosis, mast cell TET2 gene mutation exists in [14, 26-28]. In the AML study found that nearly $10 \%$ of patients with TET2 gene mutation, and the mutation is heterozygous mutations, wildtype allele has not changed, indicating that TET2 may play a role in inhibiting the occurrence of tumors [29]. TET2 protein can catalyze the demethylation of DNA and regulate the whole and the site. Therefore, the mutation of TET2 may lead to the imbalance of epigenetic regulation, leading to the occurrence and development of tumors. In a large scale study of primary AML, Metzeler et al. [30] found that the mutation rate of TET 2 was $23 \%$, and the mutation rate of TET2 increased with age. In our study, compared with the normal tissue expression of TET2 in AML decreased or absent, suggesting that its expression is closely related with the occurrence of AML, we observed that TET2 in AML this law in the process of change was confirmed in the experimental study of Yang [31] people, they found that TET protein expression decreased in the family liver cancer and colon cancer, breast cancer. A large number of epigenetic studies have demonstrated that TET gene mutation is involved in the pathogenesis of bone marrow malignancies [32]. The mutation was detected in the early and late stages of tumorigenesis. In addition, other studies have shown that miR-22 can affect the prognosis of breast cancer by inhibiting the expression of TET gene, and confirmed the TET gene related to tumor prognosis on the other side [32]. Our study also confirmed that miR-22 could inhibit the expression of AML and promote the increase of white blood cells by inhibiting the expression of TET2 gene. Therefore, we do not rule out the possibility that TET2 gene interacts with miRNA to achieve the function of tumor suppressor function.

Our study will analyze AML in TET2 inactivation and MEG3relationship, and further explore the relationship between TET 2 and $\mathrm{miR}-22-3 \mathrm{p} / 5 \mathrm{p}$, the latter will continue to study MEG3, TET2, the relationship between miR-22$3 \mathrm{p} / 5 \mathrm{p}$, to determine the molecular mechanism of MEG3 inactivation. Our study may further reveal the molecular mechanism of AML and provide a new theoretical basis for the study of the disease.

\section{MATERIALS AND METHODS}

\section{Clinical samples}

With the approval of institutional review board and human ethics committee, a total of 26 AML cases between February 2014 and August 2015 in the People's
Hospital of Hainan Province which were diagnosed with AML according to the French-American-British (FAB) criteria.20 healthy volunteers in our study were randomly obtained from the Hainan. All of the tissues were histologically examined by two senior pathologists at Department of Pathology of the Hospital based on World Health Organization (WHO) criteria.

\section{Cell culture}

The human AML cell line K562 was obtained from the Biofavor Biotech (Wuhan, China). Cells were incubated 1640 medium (GIBCO, USA), supplemented with 10\% fetal bovine serum (Gibco, Auckland, New Zealand)

\section{DNA extraction, sodium bisulfite modification, and PCR}

Genomic DNA from tissue samples was extracted using the Tissue DNA Kit (Qiagen) according to the manufacturer's recommendations. Bisulfite modification of genomic DNA was performed using the EZ DNA Methylation Kit (Zymo Research) according to the manufacturer's protocol. Bisulfite-treated genomic DNA was amplified in a 384-well plate using HotStarTaq Polymerase in a 5- $\mu$ l reaction volume (Qiagen). PCR conditions were $94{ }^{\circ} \mathrm{C}$ for 4 min followed by 45 cycles of $95{ }^{\circ} \mathrm{C}$ for $20 \mathrm{~s}, 56{ }^{\circ} \mathrm{C}$ for $20 \mathrm{~s}$, and $72{ }^{\circ} \mathrm{C}$ for $60 \mathrm{~s}$, with a final extension of $72{ }^{\circ} \mathrm{C}$ for $3 \mathrm{~min}$. Primer sequences are TET2FCTCCTGTTGAGTTACAACGCT;TET2 RACATGGTTGGTTCTATCCTGTTC;ME G3FTCTATGAAGACCAGTATGGCGTG; MEG3RCACTTCTTGCTGTCCTCCTG;

\section{Quantitative real-time PCR}

Total RNA was extracted from frozen tissue samples or cells using the TRIzol reagent (Invitrogen, Shanghai, China) according to the manufacturer's protocol. A total of $1 \mu \mathrm{g}$ of RNA was reverse transcribed using the TIANScript RT Kit (TIANGEN, Beijing, China). Quantitative realtime PCR was performed using the BIO-RAD iQ5 RealTime System (BIO-RAD, Hercules, CA, USA) and SYBR Green (TIANGEN) as a double-stranded DNA-specific dye. We performed the cDNA synthesis using a Thermo Script RT-qPCR System (Invitrogen). Target genes were amplified with primers designed using the Primer Premier Version 5.0 software.

\section{Transfection}

TET2-siRNA, miRNA-22-3p mimics, miRNA$22-5 \mathrm{p}$ mimics, to cells for $24 \mathrm{~h}$ for loss-of-function experiments using Lipofectamine 2000 (Invitrogen) according to the manufacturer's instructions. The NC scrambled oligonucleotide does not encode for any 
known lncRNA. Transfection efficiency was verified by SYBR Green real-time PCR detection of TET2, MEG3 expression.

\section{Detection of cell reproductive capacity}

Cells in TET2-siRNA1 group, TET2-siRNA2group, and miRNA-22-3p mimics group and miRNA-22-5p mimics, $\mathrm{NC}$ group, and normal group were inoculated in 96-well plate. After 24h, 36h, 48h after inoculation, 10 $\mu \mathrm{lCCK} 8$ was added per well the optical density at 450 $\mathrm{nm}$ was measured after 4 hour of incubation at $37.0^{\circ} \mathrm{C}$ using a Tecan Infinite M200 Multimode microplate reader (Mechelen, Belgium). Each experiment was performed 3 times. With 3 ventral orifices in each group, the experiment was repeated for three times.

\section{Statistical analysis}

The SPSS 17.0 statistical software (SPSS Inc., Chicago, IL, USA) and Microsoft Excel (Microsoft Corporation, Redmond, WA, USA) were used for statistical analysis. The non-normal measurement data were represented by Median. Bilateral Mann-Whitney U test was used in comparison between two groups. They were shown as mean $\pm \mathrm{SD}$. To explore the correlation between TET2 and MEG3expression, two-tailed Chisquared test was employed. Differences between the groups were compared using the Student's t test, and results were considered statistically significant at $\mathrm{P}<0.05$.

\section{ACKNOWLEDGMENTS}

This work was supported by the National Natural Science Foundation of China (No. 81460031) and Demonstration promotion special application technology research and development of hainan province (NO. ZDXM2014119). The authors declare that they have no competing interests. We thank all of the participants for their involvement in this study.

\section{CONFLICTS OF INTEREST}

The authors declare that there are no conflicts of interest.

\section{REFERENCES}

1. Babushok DV, Bessler M, Olson TS. Genetic predisposition to myelodysplastic syndrome and acute myeloid leukemia in children and young adults. Leuk Lymphoma. 2016; 57:520-536.

2. Siegel RL, Miller KD, Jemal A. Cancer statistics, 2015. CA Cancer J Clin. 2015; 65:5-29.
3. Scholl C, Gilliland DG, Frohling S. Deregulation of signaling pathways in acute myeloid leukemia. Semin Oncol. 2008; 35:336-345.

4. Schaukowitch K, Kim TK. Emerging epigenetic mechanisms of long non-coding RNAs. Neuroscience. 2014; 264:25-38.

5. Rinn JL, Chang HY. Genome regulation by long noncoding RNAs. Annu Rev Biochem. 2012; 81:145-166.

6. Zhao T, Xu J, Liu L, Bai J, Xu C, Xiao Y, Li X, Zhang L. Identification of cancer-related IncRNAs through integrating genome, regulome and transcriptome features. Mol Biosyst. 2015; 11:126-136.

7. Han BW, Chen YQ. Potential pathological and functional links between long noncoding RNAs and hematopoiesis. Sci Signal. 2013; 6:re5.

8. Zhou Y, Zhong Y, Wang Y, Zhang X, Batista DL, Gejman R, Ansell PJ, Zhao J, Weng C, Klibanski A. Activation of p53 by MEG3 non-coding RNA. J Biol Chem. 2007; 282:24731-24742.

9. Balik V, Srovnal J, Sulla I, Kalita O, Foltanova T, Vaverka M, Hrabalek L, Hajduch M. MEG3: a novel long noncoding potentially tumour-suppressing RNA in meningiomas. $\mathrm{J}$ Neurooncol. 2013; 112:1-8.

10. Zhang X, Rice K, Wang Y, Chen W, Zhong Y, Nakayama Y, Zhou Y, Klibanski A. Maternally expressed gene 3 (MEG3) noncoding ribonucleic acid: isoform structure, expression, and functions. Endocrinology. 2010; 151:939-947.

11. Zhang X, Zhou Y, Mehta KR, Danila DC, Scolavino S, Johnson SR, Klibanski A. A pituitary-derived MEG3 isoform functions as a growth suppressor in tumor cells. J Clin Endocrinol Metab. 2003; 88:5119-5126.

12. Zhang X, Gejman R, Mahta A, Zhong Y, Rice KA, Zhou Y, Cheunsuchon P, Louis DN, Klibanski A. Maternally expressed gene 3, an imprinted noncoding RNA gene, is associated with meningioma pathogenesis and progression. Cancer Res. 2010; 70:2350-2358.

13. Benetatos L, Hatzimichael E, Dasoula A, Dranitsaris G, Tsiara S, Syrrou M, Georgiou I, Bourantas KL. CpG methylation analysis of the MEG3 and SNRPN imprinted genes in acute myeloid leukemia and myelodysplastic syndromes. Leuk Res. 2010; 34:148-153.

14. Langlois T, da Costa Reis Monte-Mor B, Lenglet G, Droin N, Marty C, Le Couedic JP, Almire C, Auger N, Mercher T, Delhommeau F, Christensen J, Helin K, Debili N, et al. TET2 deficiency inhibits mesoderm and hematopoietic differentiation in human embryonic stem cells. Stem Cells. 2014; 32:2084-2097.

15. Ko M, Rao A. TET2: epigenetic safeguard for HSC. Blood. 2011; 118:4501-4503.

16. Tahiliani M, Koh KP, Shen Y, Pastor WA, Bandukwala H, Brudno Y, Agarwal S, Iyer LM, Liu DR, Aravind L, Rao A. Conversion of 5-methylcytosine to 5-hydroxymethylcytosine in mammalian DNA by MLL partner TET1. Science. 2009; 324:930-935. 
17. Ito S, D'Alessio AC, Taranova OV, Hong K, Sowers LC, Zhang Y. Role of Tet proteins in $5 \mathrm{mC}$ to $5 \mathrm{hmC}$ conversion, ES-cell self-renewal and inner cell mass specification. Nature. 2010; 466:1129-1133.

18. Ito S, Shen L, Dai Q, Wu SC, Collins LB, Swenberg JA, He C, Zhang Y. Tet proteins can convert 5-methylcytosine to 5-formylcytosine and 5-carboxylcytosine. Science. 2011; 333:1300-1303.

19. Cimmino L, Abdel-Wahab O, Levine RL, Aifantis I. TET family proteins and their role in stem cell differentiation and transformation. Cell Stem Cell. 2011; 9:193-204.

20. Miyoshi N, Wagatsuma H, Wakana S, Shiroishi T, Nomura M, Aisaka K, Kohda T, Surani MA, Kaneko-Ishino T, Ishino F. Identification of an imprinted gene, Meg3/Gtl2 and its human homologue MEG3, first mapped on mouse distal chromosome 12 and human chromosome 14q. Genes Cells. 2000; 5:211-220.

21. Astuti D, Latif F, Wagner K, Gentle D, Cooper WN, Catchpoole D, Grundy R, Ferguson-Smith AC, Maher ER. Epigenetic alteration at the DLK1-GTL2 imprinted domain in human neoplasia: analysis of neuroblastoma, phaeochromocytoma and Wilms' tumour. Br J Cancer. 2005; 92:1574-1580.

22. Braconi C, Kogure T, Valeri N, Huang N, Nuovo G, Costinean S, Negrini M, Miotto E, Croce CM, Patel T. microRNA-29 can regulate expression of the long non-coding RNA gene MEG3 in hepatocellular cancer. Oncogene. 2011; 30:4750-4756.

23. Benetatos L, Vartholomatos G, Hatzimichael E. MEG3 imprinted gene contribution in tumorigenesis. Int $\mathrm{J}$ Cancer. 2011; 129:773-779.

24. Lu KH, Li W, Liu XH, Sun M, Zhang ML, Wu WQ, Xie WP, Hou YY. Long non-coding RNA MEG3 inhibits NSCLC cells proliferation and induces apoptosis by affecting p53 expression. BMC Cancer. 2013; 13:461.

25. Delhommeau F, Dupont S, Della Valle V, James C, Trannoy S, Masse A, Kosmider O, Le Couedic JP, Robert F, Alberdi A, Lecluse Y, Plo I, Dreyfus FJ, et al. Mutation in TET2 in myeloid cancers. N Engl J Med. 2009; 360:2289-2301.

26. Jardin F, Ruminy P, Parmentier F, Troussard X, Vaida I, Stamatoullas A, Lepretre S, Penther D, Duval AB,
Picquenot JM, Courville P, Capiod JC, Tilly H, et al. TET2 and TP53 mutations are frequently observed in blastic plasmacytoid dendritic cell neoplasm. Br J Haematol. 2011; 153:413-416.

27. Makishima H, Jankowska AM, McDevitt MA, O'Keefe C, Dujardin S, Cazzolli H, Przychodzen B, Prince C, Nicoll J, Siddaiah H, Shaik M, Szpurka H, Hsi E, et al. CBL, CBLB, TET2, ASXL1, and IDH1/2 mutations and additional chromosomal aberrations constitute molecular events in chronic myelogenous leukemia. Blood. 2011; 117:e198-e206.

28. Tefferi A, Pardanani A, Lim KH, Abdel-Wahab O, Lasho TL, Patel J, Gangat N, Finke CM, Schwager S, Mullally A, Li CY, Hanson CA, Mesa R, et al. TET2 mutations and their clinical correlates in polycythemia vera, essential thrombocythemia and myelofibrosis. Leukemia. 2009; 23:905-911.

29. Gaidzik VI, Paschka P, Spath D, Habdank M, Kohne $\mathrm{CH}$, Germing U, von Lilienfeld-Toal M, Held G, Horst HA, Haase D, Bentz M, Gotze K, Dohner H, et al. TET2 mutations in acute myeloid leukemia (AML): results from a comprehensive genetic and clinical analysis of the AML study group. J Clin Oncol. 2012; 30:1350-1357.

30. Metzeler KH, Maharry K, Radmacher MD, Mrozek K, Margeson D, Becker H, Curfman J, Holland KB, Schwind S, Whitman SP, Wu YZ, Blum W, Powell BL, et al. TET2 mutations improve the new European LeukemiaNet risk classification of acute myeloid leukemia: a Cancer and Leukemia Group B study. J Clin Oncol. 2011; 29:1373-1381

31. Yang H, Liu Y, Bai F, Zhang JY, Ma SH, Liu J, Xu ZD, Zhu HG, Ling ZQ, Ye D, Guan KL, Xiong Y. Tumor development is associated with decrease of TET gene expression and 5-methylcytosine hydroxylation. Oncogene. 2013; 32:663-669.

32. Song SJ, Poliseno L, Song MS, Ala U, Webster K, Ng C, Beringer G, Brikbak NJ, Yuan X, Cantley LC, Richardson AL, Pandolfi PP. MicroRNA-antagonism regulates breast cancer stemness and metastasis via TET-family-dependent chromatin remodeling. Cell. 2013; 154:311-324. 